\title{
Reactions of 4-diphenylphosphino benzoic acid with organotin oxides and -oxy-hydroxide
}

\author{
RAMAKIRUSHNAN SURIYA NARAYANAN ${ }^{\mathrm{a}}$, PAKKIRISAMY THILAGAR ${ }^{\mathrm{b}}$, \\ JOYDEV ACHARYA ${ }^{\mathrm{c}}$, PAWAN KUMAR ${ }^{\mathrm{c}}$, DODDAPUNENI KRISHNA RAO ${ }^{\mathrm{a}}$, \\ VADAPALLI CHANDRASEKHAR ${ }^{\mathrm{a}, \mathrm{c}, *}$ and ANUKUL JANA ${ }^{\mathrm{a}, * \mathbb{C}}$ \\ aTata Institute of Fundamental Research Hyderabad, Gopanpally, Hyderabad, Telangana 500 107, India \\ ${ }^{b}$ Department of Inorganic and Physical Chemistry, Indian Institute of Science, Bangalore, Karnataka 560012 , \\ India \\ ${ }^{\mathrm{c}}$ Department of Chemistry, Indian Institute of Technology Kanpur, Kanpur, Uttar Pradesh 208 016, India \\ E-mail: vc@iitk.ac.in; ajana@tifrh.res.in
}

MS received 24 March 2018; revised 9 May 2018; accepted 13 May 2018; published online 9 July 2018

\begin{abstract}
The reactions of $p$-diphenylphosphinobenzoic acid $(\mathrm{LCOOH})$ with various organotin precursors have been carried out. Accordingly, the reaction of $\left[n-\mathrm{BuSn}(\mathrm{O})(\mathrm{OH}]_{\mathrm{n}}\right.$ with $\mathrm{LCOOH}$ afforded the hexameric compound, $\left[n-\mathrm{BuSn}(\mathrm{O}) \mathrm{O}_{2} \mathrm{C}-\mathrm{C}_{6} \mathrm{H}_{4}-p-\mathrm{PPh}_{2}\right]_{6}(\mathbf{1})$. On the other hand, the reaction of $\mathrm{LCOOH}$ with $\left[n-\mathrm{Bu}_{2} \mathrm{SnO}\right]_{\mathrm{n}}$ gave the tetrameric compound $\left[\left\{n-\mathrm{Bu}_{2} \mathrm{SnO}_{2} \mathrm{C}-\mathrm{C}_{6} \mathrm{H}_{4}-p-\mathrm{PPh}_{2}\right\}_{2} \mathrm{O}\right]_{2}$ (2). The 1-D coordination polymers $\left[\mathrm{R}_{3} \mathrm{SnO}_{2} \mathrm{C}-\mathrm{C}_{6} \mathrm{H}_{4}-p-\mathrm{P}(\mathrm{O}) \mathrm{Ph}_{2}\right]_{\mathrm{n}},[\mathrm{R}=n-\mathrm{Bu}(3), \mathrm{R}=\mathrm{Ph}(\mathbf{4})]$ were prepared in the reaction of $\left[n-\mathrm{Bu}_{3} \mathrm{Sn}\right]_{2} \mathrm{O}$ or $\left[\mathrm{Ph}_{3} \mathrm{Sn}\right]_{2} \mathrm{O}$ with $\mathrm{LCOOH}$. The compounds 1-4 were structurally characterized by multinuclear NMR spectroscopic and single crystal X-ray diffraction studies.
\end{abstract}

Keywords. Organostannoxane; multisite coordination ligand; organotin compounds; 1-D coordination polymer.

\section{Introduction}

The modular design of clusters, cages and coordination polymers remains an exciting goal for researchers owing to the novel structural and applicative aspects. ${ }^{1,2}$ Organotin carboxylates offer an opportunity to design functional molecules since a reasonable stoichiometric control exists in the product formation involving the reaction of an organotin oxide/oxide-hydroxide with carboxylic acids. A precise control of structure is thereby possible with the additional advantage that most of these compounds can be obtained in a simple one-pot reaction between the organotin precursors and carboxylic acids. ${ }^{3-9}$ Utilizing this strategy, various organostannoxanes were synthesised that possessed diverse functional groups ranging from being electroactive to photoactive. ${ }^{10,11}$ We have been interested to use this well-tested methodology to assemble coordination ligands supported on organostannoxane frameworks. ${ }^{12}$
In one such endeavour, we have shown that phosphine containing organostannoxanes could be successfully utilized to support palladium nanoparticles. Such hybrid systems were also shown to be catalytically active for various organic transformations. ${ }^{13-15}$ However, in these studies we were unable to structurally characterize the parent ligand. With this in mind and also to modulate the nuclearity and structural topology of such phosphinecontaining organostannoxanes, we have carried out the reactions $p$-diphenylphosphinobenzoic acid ( $\mathrm{LCOOH})$ with various organotin precursors which resulted in the isolation of $\left[n-\mathrm{BuSn}(\mathrm{O}) \mathrm{O}_{2} \mathrm{C}-\mathrm{C}_{6} \mathrm{H}_{4}-p-\mathrm{PPh}_{2}\right]_{6}$ (1), $\left[\left\{n-\mathrm{Bu}_{2} \mathrm{SnO}_{2} \mathrm{C}-\mathrm{C}_{6} \mathrm{H}_{4}-p-\mathrm{PPh}_{2}\right\}_{2} \mathrm{O}\right]_{2}(2)$ and $\left[\mathrm{R}_{3} \mathrm{SnO}_{2} \mathrm{C}-\right.$ $\left.\mathrm{C}_{6} \mathrm{H}_{4}-p-\mathrm{P}(\mathrm{O}) \mathrm{Ph}_{2}\right]_{\mathrm{n}},[\mathrm{R}=n$ - $\mathrm{Bu}(3), \mathrm{R}=\mathrm{Ph}(\mathbf{4})]$. While $\mathbf{1}$ and $\mathbf{2}$ are molecular compounds possessing a drum (prismane) and a ladder structure respectively, $\mathbf{3}$ and $\mathbf{4}$ are coordination polymers. The synthesis and structural characterization of 1-4 are described, herein.

\footnotetext{
*For correspondence

Electronic supplementary material: The online version of this article (https://doi.org/10.1007/s12039-018-1493-5) contains supplementary material, which is available to authorized users.
} 


\section{Experimental}

\subsection{Materials and physical measurements}

$[n-\mathrm{BuSn}(\mathrm{O}) \mathrm{OH}]_{\mathrm{n}},\left(n-\mathrm{Bu}_{2} \mathrm{SnO}\right)_{\mathrm{n}},\left(n-\mathrm{Bu}_{3} \mathrm{Sn}\right)_{2} \mathrm{O},\left(\mathrm{Ph}_{3} \mathrm{Sn}\right)_{2} \mathrm{O}$ and 4-(diphenylphosphino)benzoic acid were purchased from Sigma Aldrich and were used as such without further purification. Solvents were stored over appropriate reagents and distilled under nitrogen prior to use. Melting points were measured using a JSGW apparatus and are uncorrected. Elemental analyses were carried out by using a Thermo quest CE instrument model EA/110 CHNS-O elemental analyser. ${ }^{1} \mathrm{H},{ }^{13} \mathrm{P}$ and ${ }^{119} \mathrm{Sn}$ NMR were recorded on a JEOL-JNM LAMBDA 400 model NMR spectrometer or on a BrukerNanoBay $300 \mathrm{MHz}$ NMR spectrometer. The chemical shifts are referenced with respect to tetramethylsilane $\left({ }^{1} \mathrm{H}\right), 85 \%$ $\mathrm{H}_{3} \mathrm{PO}_{4}\left({ }^{31} \mathrm{P}\right)$ and tetramethyltin $\left({ }^{119} \mathrm{Sn}\right)$, respectively.

\subsection{Synthetic procedures of compounds $\mathbf{1 - 4}$}

Appropriate organotin precursors (1 equiv.) and $p$-(diphenylphosphino)benzoic acid ( 1 or 2 equiv.) were taken together in toluene $(80 \mathrm{~mL})$ and heated under reflux for $6 \mathrm{~h}$. The water formed in the reaction was removed by using a Dean-Stark apparatus. The reaction mixture was filtered and evaporated to afford a solid which was identified as the title products.

2.2a Compound 1: $\quad[n-\mathrm{BuSn}(\mathrm{O}) \mathrm{OH}]_{\mathrm{n}}(0.30 \mathrm{~g}, 1.44 \mathrm{mmol})$ and $p$-(diphenylphosphino)benzoic acid $(0.44 \mathrm{~g}, 1.44 \mathrm{mmol}$ ). Yield: $0.70 \mathrm{~g}$ (95.0\%). M.p.: $>290{ }^{\circ} \mathrm{C}$ dec. ${ }^{1} \mathrm{H}$ NMR $\left(400.0 \mathrm{MHz}, \mathrm{CDCl}_{3}\right): 0.81$ (t, 18H), $1.32(\mathrm{~m}, 12 \mathrm{H})$, $1.50(\mathrm{~m}, 12 \mathrm{H}), 1.73(\mathrm{~m}, 12 \mathrm{H}), 7.23(\mathrm{~m}, 60 \mathrm{H}), 7.91(\mathrm{~m}$, 24H) ppm. ${ }^{31} \mathrm{P}\left\{{ }^{1} \mathrm{H}\right\}$ NMR $\left(161.0 \mathrm{MHz}, \mathrm{CDCl}_{3}\right):-4.6(\mathrm{~s})$ ppm. ${ }^{119} \mathrm{Sn}\left\{{ }^{1} \mathrm{H}\right\}$ NMR $\left(150.0 \mathrm{MHz}, \mathrm{CDCl}_{3}\right):-481.0$ (s) ppm. Anal. Calcd. for $\mathrm{C}_{152} \mathrm{H}_{154} \mathrm{O}_{18} \mathrm{P}_{6} \mathrm{Sn}_{6}$ (including two molecules of toluene): C,57.65; H, 4.90\%. Found: C, 57.41; $\mathrm{H}, 4.87 \%$. Crystals suitable for X-ray diffraction study were obtained from the solution of $\mathbf{1}$ in toluene.

$2.2 \mathrm{~b}$ Compound 2: $\quad\left[n-\mathrm{Bu}_{2} \mathrm{Sn}(\mathrm{O})\right]_{\mathrm{n}}(0.10 \mathrm{~g}, 0.40 \mathrm{mmol})$ and $p$-(diphenylphosphino)benzoic acid $(0.12 \mathrm{~g}, 0.40 \mathrm{mmol})$. Yield: $0.20 \mathrm{~g}(91.7 \%) .{ }^{1} \mathrm{H}$ NMR $\left(300.1 \mathrm{MHz}, \mathrm{C}_{6} \mathrm{D}_{6}\right)$ : $0.81(\mathrm{t}, 24 \mathrm{H}), 1.32(\mathrm{~m}, 16 \mathrm{H}), 1.50(\mathrm{~m}, 16 \mathrm{H}), 1.73(\mathrm{~m}$, 16H), $7.23(\mathrm{~m}, 40 \mathrm{H}), 7.91(\mathrm{~m}, 16 \mathrm{H}) \mathrm{ppm} .{ }^{31} \mathrm{P}\left\{{ }^{1} \mathrm{H}\right\}$ NMR (121.5 MHz, $\left.\mathrm{C}_{6} \mathrm{D}_{6}\right)$ : -5.1 (s) ppm. ${ }^{119} \mathrm{Sn}\left\{{ }^{1} \mathrm{H}\right\}$ NMR (111.9 $\mathrm{MHz}, \mathrm{C}_{6} \mathrm{D}_{6}$ ): -241.1 (s) and -253.2 (s) ppm. Anal. Calcd. for $\mathrm{C}_{108} \mathrm{H}_{128} \mathrm{O}_{10} \mathrm{P}_{4} \mathrm{Sn}_{4}$ : C, 59.3; H, 5.91\%. Found: C, 57.7; H, $6.08 \%$. Suitable crystals for single crystal X-ray diffraction were obtained from the solution of $\mathbf{2}$ in dichloromethane.

2.2c Compound 3: $\quad\left(n-\mathrm{Bu}_{3} \mathrm{Sn}\right)_{2} \mathrm{O}(0.50 \mathrm{~g}, 0.84 \mathrm{mmol})$ and $p$-(diphenylphosphino)benzoic acid $(0.51 \mathrm{~g}, 1.68 \mathrm{mmol})$ Yield: $1.00 \mathrm{~g}(92.6 \%) .{ }^{1} \mathrm{H}$ NMR $\left(300.1 \mathrm{MHz}, \mathrm{CDCl}_{3}\right)$ : 0.81 $(\mathrm{t}, 9 \mathrm{H}), 1.32(\mathrm{~m}, 6 \mathrm{H}), 1.50(\mathrm{~m}, 6 \mathrm{H}), 1.73(\mathrm{~m}, 6 \mathrm{H}), 7.23$ $(\mathrm{m}, 10 \mathrm{H}), 7.91(\mathrm{~m}, 4 \mathrm{H}) \mathrm{ppm} .{ }^{31} \mathrm{P}\left\{{ }^{1} \mathrm{H}\right\}$ NMR $(121.5 \mathrm{MHz}$, $\left.\mathrm{CDCl}_{3}\right): 28.7(\mathrm{~s}) \mathrm{ppm} .{ }^{119} \mathrm{Sn}\left\{{ }^{1} \mathrm{H}\right\}$ NMR $\left(111.9 \mathrm{MHz}, \mathrm{CDCl}_{3}\right)$ : 91.4(s) ppm. Anal. Calcd. for $\mathrm{C}_{33} \mathrm{H}_{47} \mathrm{O}_{3} \mathrm{PSn}$ : C, 61.79; H,
7.39\%. Found: C, 59.59; H, 6.83\%. Crystals suitable for X-ray diffraction were obtained from the solution of 3 in chloroform.

2.2d Compound 4: $\left(\mathrm{Ph}_{3} \mathrm{Sn}\right)_{2} \mathrm{O}(0.50 \mathrm{~g}, 0.70 \mathrm{mmol})$ and $p$-(diphenylphosphino)benzoic acid $(0.42 \mathrm{~g}, 1.4 \mathrm{mmol})$ Yield: $0.90 \mathrm{~g}$ (91.6\%). M.p.: ${ }^{1} \mathrm{H}$ NMR $\left(400.0 \mathrm{MHz}, \mathrm{CDCl}_{3}\right)$ : 7.22-7.96 (m, 29H) ppm. ${ }^{31} \mathrm{P}\left\{{ }^{1} \mathrm{H}\right\}$ NMR $(161.0 \mathrm{MHz}$, $\mathrm{CDCl}_{3}$ ): 29.9(s) ppm. ${ }^{119} \mathrm{Sn}\left\{{ }^{1} \mathrm{H}\right\} \mathrm{NMR}\left(150.0 \mathrm{MHz}, \mathrm{CDCl}_{3}\right)$ : -117.1(s) ppm. Anal. Calcd. for $\mathrm{C}_{61} \mathrm{H}_{50} \mathrm{O}_{3} \mathrm{PSn}_{2}$ : C, 66.64; H, 4.58\%. Found: C, 66.53; H, 4.55\%. Crystals suitable for $\mathrm{X}$-ray diffraction were obtained from the mother liquor of $\mathbf{4}$ in benzene.

\section{$2.3 X$-ray crystallography}

Single crystal X-ray data of $\mathbf{1}, \mathbf{3}$ and $\mathbf{4}$ were collected at 100 $\mathrm{K}$ on a Bruker SMART APEX CCD diffractometer using graphite-monochromated Mo K $\alpha$ radiation $(\lambda=0.71069 \AA)$. The linear absorption coefficients, scattering factors for the atoms, and the anomalous dispersion corrections were taken from International Tables for X-ray Crystallography. ${ }^{16}$ Data integration and reduction were processed with SAINT software. ${ }^{17}$ An empirical absorption correction was applied to the collected reflections with SADABS ${ }^{18}$ using XPREP. Diffraction data of 2 was collected at low temperature $(120 \mathrm{~K})$ using Rigaku diffractometer with Mo $K \alpha$ radiation, $\lambda=$ $0.71073 \AA$ A. Data integration and reduction were processed with CrysAlisPro software. ${ }^{19}$ An empirical absorption correction was applied to the collected reflections with SCALE3 ABSPACK integrated with CrysAlisPro. The structure was solved by intrinsic phasing method using SHELXT ${ }^{20}$ program and refined by full matrix least-squares method based on $\mathrm{F}^{2}$ by using SHELXL ${ }^{21}$ program through Olex 2 interface. ${ }^{22}$ One of the disordered butyl group in compound 1 was treated with PART instruction and refined. ${ }^{23}$ All the crystallographic figures were been created by using Diamond $3.2 \mathrm{k}$ software. ${ }^{24}$ The crystal and refinement parameters for 1-4 were given in Table 1.

\section{Results and Discussion}

\subsection{Synthesis and characterization}

The reaction of the organotin oxide-hydroxide $n$ - $\mathrm{BuSn}(\mathrm{O}) \mathrm{OH}$ with any carboxylic acid, $\mathrm{RCOOH}$, in a 6:6 ratio is known to afford the hexameric drum-like cage $\left[n-\mathrm{BuSn}(\mathrm{O}) \mathrm{O}_{2} \mathrm{CR}\right]_{6} \cdot{ }^{3,4}$ The core of this cage is made up of a $\mathrm{Sn}_{6} \mathrm{O}_{6}$ framework which is supported by bidentate carboxylate ligands. Similarly, the reaction of $\left[n-\mathrm{Bu}_{2} \mathrm{Sn}(\mathrm{O})\right]_{n}$ with any simple mono carboxylic acid, in a 4:4 ratio tends to form a tetraorganotin ladder compound $\left[\left\{n-\mathrm{Bu}_{2} \mathrm{SnO}_{2} \mathrm{CR}\right\}_{2} \mathrm{O}\right]_{2}$. We were interested to utilize this modular approach for preparing the designer multi-site coordinating ligands. Accordingly, the reaction of $\mathrm{RCOOH}(\mathrm{R}=$ $\left.p-\mathrm{PPh}_{2}-\mathrm{C}_{6} \mathrm{H}_{4}\right)$ with $[n-\mathrm{BuSn}(\mathrm{O}) \mathrm{OH}]_{\mathrm{n}} /\left[n-\mathrm{Bu}_{2} \mathrm{Sn}(\mathrm{O})\right]_{\mathrm{n}}$ 


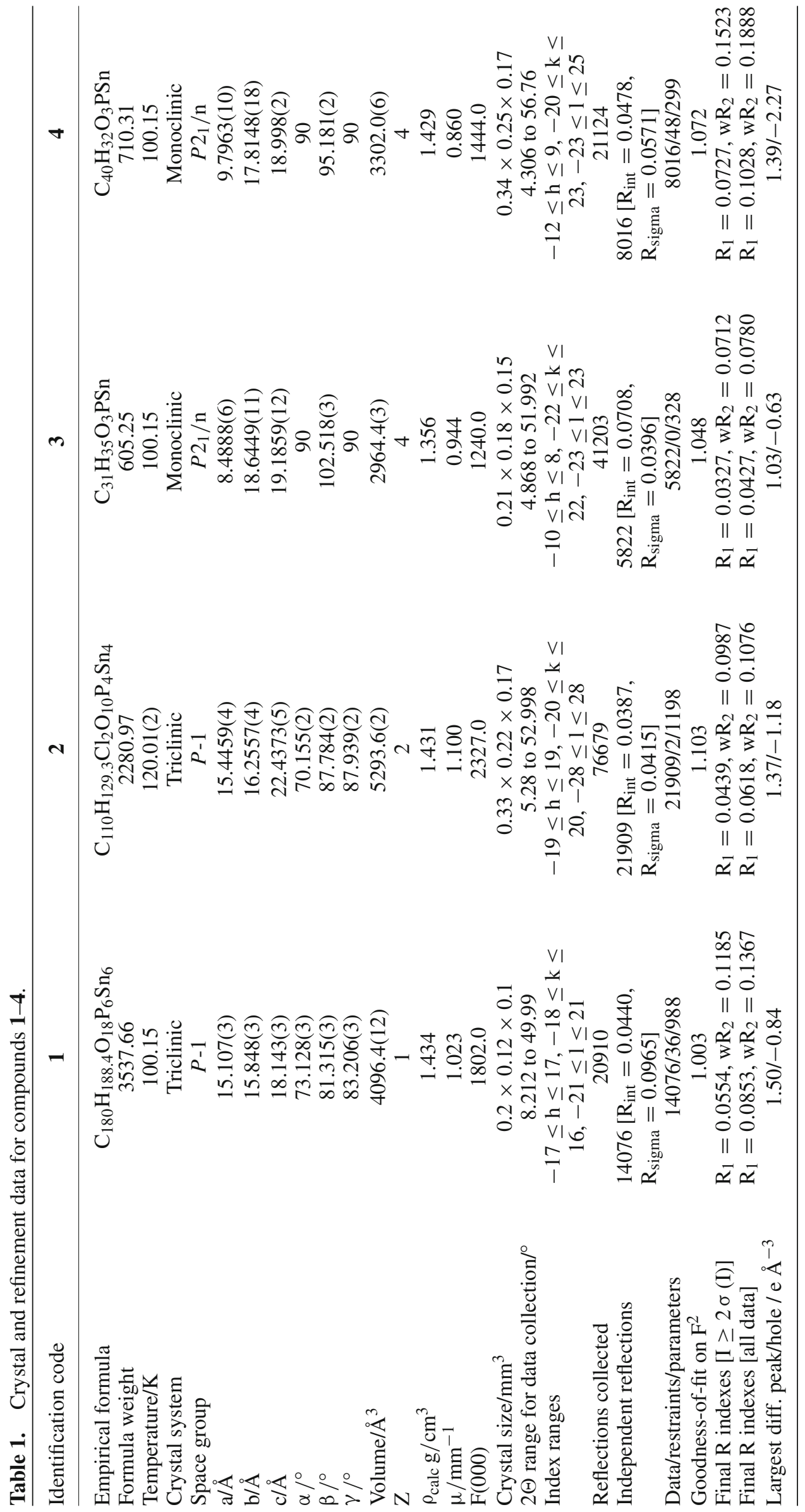




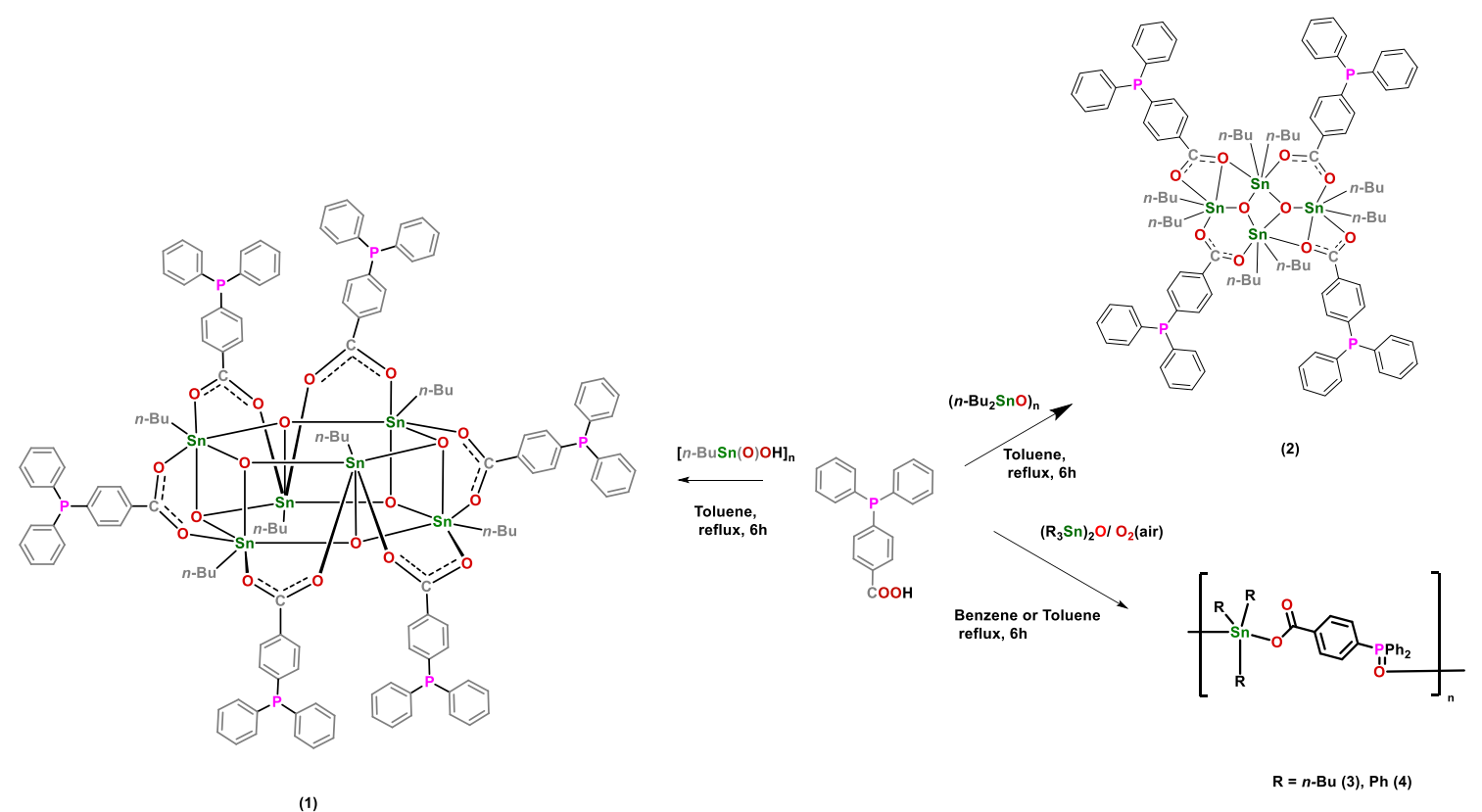

Scheme 1. Synthesis of organostannoxane compounds 1-4.

in a 1:1 stoichiometry was carried out. In accordance with our expectation the hexameric and tetrameric cages $\left[n-\mathrm{BuSn}(\mathrm{O}) \mathrm{O}_{2} \mathrm{C}-\mathrm{C}_{6} \mathrm{H}_{4}-p-\mathrm{PPh}_{2}\right]_{6}(\mathbf{1})$ and $\left[\left\{n-\mathrm{Bu}_{2}\right.\right.$ $\left.\left.\mathrm{SnO}_{2} \mathrm{C}-\mathrm{C}_{6} \mathrm{H}_{4}-p-\mathrm{PPh}_{2}\right\}_{2} \mathrm{O}\right]_{2}$ (2) were obtained in nearly quantitative yields (Scheme 1). Presence of a characteristic single peak at $-481.0 \mathrm{ppm}$ in the ${ }^{119} \mathrm{Sn}\left\{{ }^{1} \mathrm{H}\right\}$ NMR spectra for compound 1 and two signals at -241.1 and $-251.2 \mathrm{ppm}$ for compound 2 , respectively, confirmed their formation. ${ }^{3,4,10-15}$ The ${ }^{31} \mathrm{P}\left\{{ }^{1} \mathrm{H}\right\}$ NMR spectra of $\mathbf{1}$ and 2 showed singlets at $-4.6 \mathrm{ppm}$ and $-5.0 \mathrm{ppm}$ (in $\mathrm{C}_{6} \mathrm{D}_{6}$ ), respectively. These chemical shifts are comparable to the parent ligand, 4-diphenylphosphino benzoic acid $(-4.2 \mathrm{ppm})$ indicating that the phosphine units in the organostannoxane drum are present in a similar chemical environment as in the parent ligand. ${ }^{13-15}$

When we attempted the $1: 2$ reactions of $\left(n-\mathrm{Bu}_{3} \mathrm{Sn}\right)_{2} \mathrm{O} /$ $\left(\mathrm{Ph}_{3} \mathrm{Sn}\right)_{2} \mathrm{O}$ with 4-diphenylphosphino benzoic acid instead of the monomeric products, we obtained the 1Dcoordination polymers, $\left[\mathrm{R}_{3} \mathrm{SnO}_{2} \mathrm{C}-\mathrm{C}_{6} \mathrm{H}_{4}-p-\mathrm{P}(\mathrm{O}) \mathrm{Ph}_{2}\right]_{\mathrm{n}}$, $[\mathrm{R}=n-\mathrm{Bu}(3), \mathrm{R}=\mathrm{Ph}(4)]$. During the course of the reaction the $-\mathrm{PPh}_{2}$ group of the 4-diphenylphosphino benzoic acid has been found to be oxidized to the $-\mathrm{P}(\mathrm{O}) \mathrm{Ph}_{2}$ group. The $\mathrm{P}=\mathrm{O}$ unit of the latter assists in the coordination polymer formation. This is evidenced by the ${ }^{31} \mathrm{P}\left\{{ }^{1} \mathrm{H}\right\}$ and ${ }^{119} \mathrm{Sn}\left\{{ }^{1} \mathrm{H}\right\}$ NMR shift values of 29.0 (s), -117.1 (s), respectively, for $\mathrm{P}=\mathrm{O}$ moiety and five coordinate tin atom.

\subsection{X-ray crystallographic structural analysis}

The molecular structure of compound $\mathbf{1}$ is shown in Figure 1(a) revealing a dendrimer-type architecture containing a central stannoxane core from which emerge six radial arms containing the $\mathrm{PPh}_{2}$ groups. (Figure 1(b)). The $\operatorname{Sn}_{6} \mathrm{O}_{6}$ core of the stannoxane cage is comprised of two puckered $\mathrm{Sn}_{3} \mathrm{O}_{3}$ rings that are fused with each other. This results in the formation of six $\mathrm{Sn}_{2} \mathrm{O}_{2}$ four-membered rings which are present in the side of the organosatnnoxane core (Figure 1(b)). Since the carboxylate ligands are involved in a bridging (isobidentate and anisobidendate) coordination mode with alternate tin atoms of the stannoxane core, the phosphine units are automatically organized in the periphery of the stannoxane core. Each tin atom in $\mathbf{1}$ is six-coordinate $(5 \mathrm{O}, 1 \mathrm{C})$ in a distorted octahedral geometry (Figure 1(c)). The average $\mathrm{Sn}-\mathrm{O}$ bond distance is $2.115(2)$ $\AA$. The average $\mathrm{O}-\mathrm{Sn}-\mathrm{O}$ bond angles involving the four-membered distannoxane ring is $\sim 78.0^{\circ}$ while the corresponding angle in the six-membered $\mathrm{Sn}_{3} \mathrm{O}_{3}$ ring is $\sim 104.8^{\circ}$. Selected bond parameters of $\mathbf{1}$ are given in Table 2.

The molecular structure of $\mathbf{2}$ resembles the typical tetraorganotin ladder structural form. Here, a central $\left(n-\mathrm{Bu}_{2} \mathrm{Sn}\right)_{2}-\mu(\mathrm{O})_{2}$ unit is flanked on either side by two $\left(n-\mathrm{Bu}_{2} \mathrm{SnO}_{2} \mathrm{C}-\mathrm{C}_{6} \mathrm{H}_{4}-p-\mathrm{PPh}_{2}\right)$ moieties to form a ladder-type architechture via the bridging carboxylate group of the $\mathrm{O}_{2} \mathrm{C}-\mathrm{C}_{6} \mathrm{H}_{4}-p-\mathrm{PPh}_{2}$ unit (iso bidentate and anisotridendate modes). Each tin atom in $\mathbf{2}$ is sixcoordinated $(4 \mathrm{O}, 2 \mathrm{C})$ in a distorted octahedral geometry (Figure 2(c)). The average $\mathrm{Sn}-\mathrm{O}$ bond distance for Sn1A-O bonds is 2.144(3) $\AA$ and 2.180(3) $\AA$ for Sn2A$\mathrm{O}$ bonds. The average $\mathrm{Sn} 1-\mathrm{O} 1-\mathrm{Sn} 1 *, \mathrm{Sn} 1-\mathrm{O} 1-\mathrm{Sn} 2$ and O1-Sn1-O1* bond angles are $102.8(1)^{\circ}, 120.4(1)^{\circ}$ and $77.1(4)^{\circ}$ respectively (Table 3 ). 


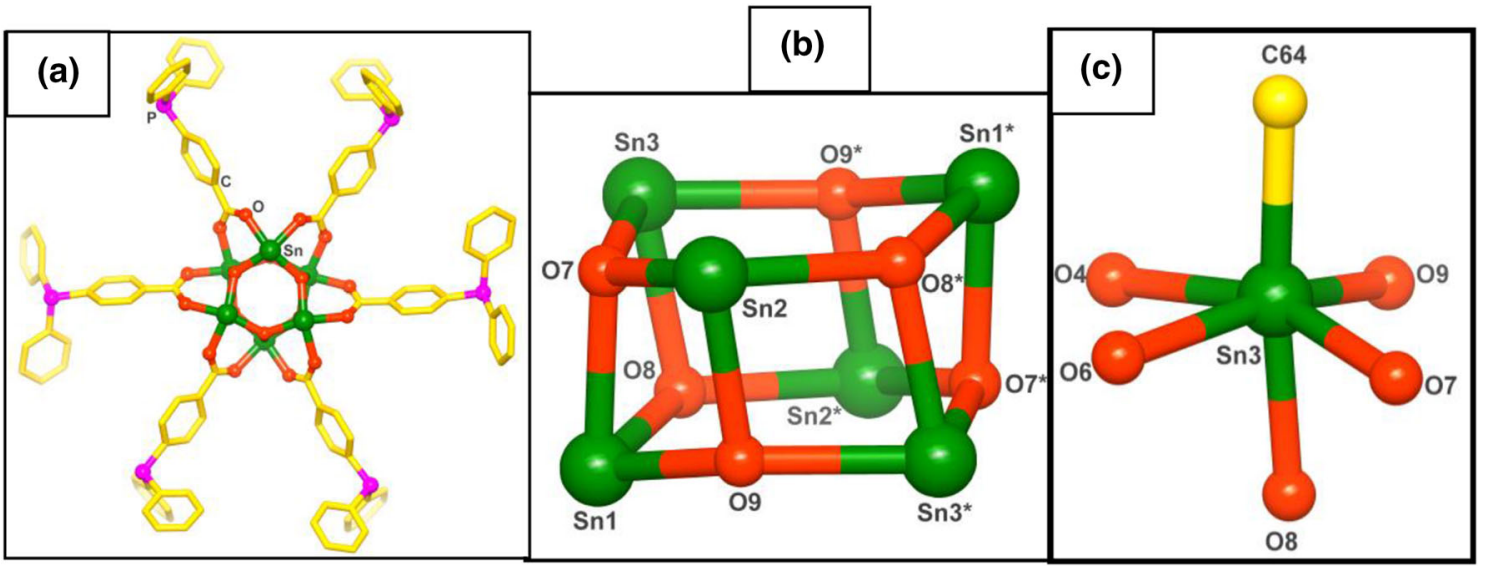

Figure 1. (a) Molecular structure of the organostannoxane drum 1. (b) A view of $\mathrm{Sn}_{6} \mathrm{O}_{6}$ core of 1. (c) Coordination environment around a tin atom (Sn3) and selected bond parameters.

Table 2. Selected bond parameters for compound $\mathbf{1 .}$

\begin{tabular}{|c|c|}
\hline Bond Lengths $(\AA)$ & Bond Angles $\left({ }^{\circ}\right)$ \\
\hline Sn1-O1 2.157(3); Sn1-O7 2.094(3) & O7-Sn1-C1 176.3(2); O9-Sn1-O8 $8^{\# 1}$ 105.06(1) \\
\hline $\mathrm{Sn} 1-\mathrm{O} 92.086(3) ; \mathrm{Sn} 2-\mathrm{O} 22.165(3)$ & O9-Sn2-C24A 177.4(3); O7-Sn2-O8 103.8(1) \\
\hline Sn2-O3 2.175(3); Sn2-O7 2.072(3) & O8-Sn3-C64 174.5(2); O9-Sn3-O7"\#1 105.4(1) \\
\hline Sn3-O4 2.162 (3); Sn3-O6 2.14 5(3) & Sn1-O9-Sn3 130.5(2); Sn2-O8-Sn1" 132.6(2) \\
\hline Sn3-O8 2.096(3); Sn1-O5 $5^{\# 1} 2.143(3)$ & Sn2-O7-Sn3 ${ }^{\# 1}$ 132.5(2); C18-P1-C9 102.1(3) \\
\hline $\mathrm{Sn} 1-\mathrm{O}^{\# 1} 2.086(3) ; \mathrm{Sn} 3-\mathrm{O} 7^{\# 1} 2.083(3)$ & C32-P2-C41 102.0(2); C52-P3-C58 104.6(3) \\
\hline
\end{tabular}

Symmetry transformations used to generate equivalent atoms: $\# 1-\mathrm{x}+1,-\mathrm{y},-\mathrm{z}+1$.

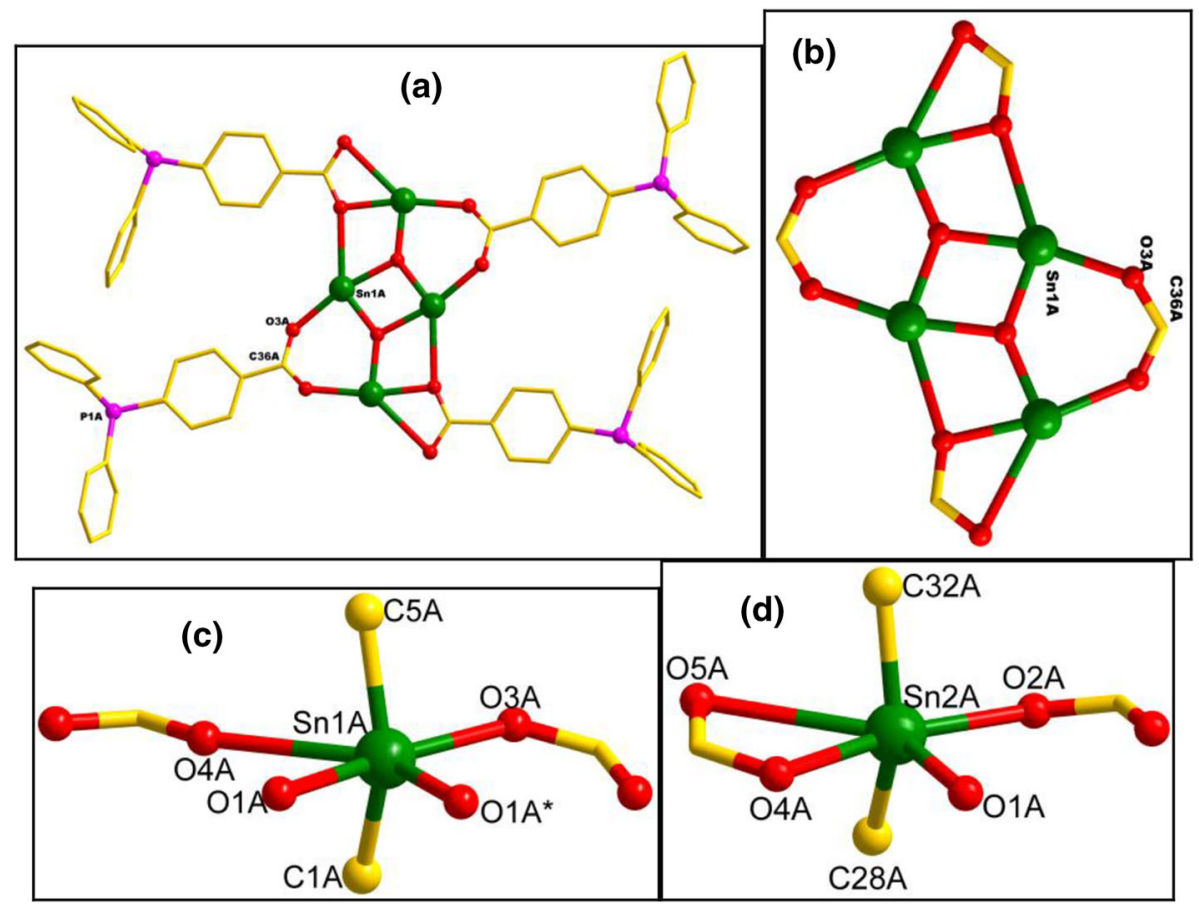

Figure 2. (a) Molecular structure of the organostannoxane ladder 2. (b) A view of $\mathrm{Sn}_{4} \mathrm{O}_{4}$ core of 2. (c) Coordination environment around a tin atoms (Sn1A and $\mathrm{Sn} 2 \mathrm{~A}$ ) and selected bond parameters. 
Table 3. Selected bond parameters for compound 2.

\begin{tabular}{|c|c|}
\hline Bond Lengths ( $\mathrm{\AA})$ & Bond Angles $\left(^{\circ}\right)$ \\
\hline $\mathrm{Sn}(1 \mathrm{~A})-\mathrm{O}(1 \mathrm{~A}) 2.033(3)$ & $\mathrm{O}(1 \mathrm{~A})-\mathrm{Sn}(1 \mathrm{~A})-\mathrm{O}(1 \mathrm{~A})^{\# 1} 77.14(11)$ \\
\hline $\operatorname{Sn}(1 \mathrm{~A})-\mathrm{O}(1 \mathrm{~A})^{\# 1} 2.170(3)$ & $\mathrm{O}(1 \mathrm{~A})^{\# 1}-\mathrm{Sn}(1 \mathrm{~A})-\mathrm{O}(3 \mathrm{~A}) 167.76(11)$ \\
\hline $\mathrm{Sn}(1 \mathrm{~A})-\mathrm{O}(3 \mathrm{~A}) 2.230(3)$ & $\mathrm{O}(1 \mathrm{~A})-\mathrm{Sn}(1 \mathrm{~A})-\mathrm{O}(3 \mathrm{~A}) 90.90(11)$ \\
\hline $\operatorname{Sn}(1 \mathrm{~A})-\mathrm{C}(5 \mathrm{~A}) 2.123(4)$ & $\mathrm{O}(1 \mathrm{~A})-\mathrm{Sn}(1 \mathrm{~A})-\mathrm{C}(5 \mathrm{~A}) 108.17(14)$ \\
\hline $\operatorname{Sn}(1 \mathrm{~A})-\mathrm{C}(1 \mathrm{~A}) 2.126(4)$ & $\mathrm{O}(1 \mathrm{~A})-\mathrm{Sn}(1 \mathrm{~A})-\mathrm{C}(1 \mathrm{~A}) 108.06(14)$ \\
\hline $\mathrm{Sn}(2 \mathrm{~A})-\mathrm{O}(1 \mathrm{~A}) 2.038(3)$ & $\mathrm{C}(5 \mathrm{~A})-\mathrm{Sn}(1 \mathrm{~A})-\mathrm{O}(1 \mathrm{~A})^{\# 1} 94.46(14)$ \\
\hline $\mathrm{Sn}(2 \mathrm{~A})-\mathrm{O}(4 \mathrm{~A}) 2.186(3)$ & $\mathrm{C}(5 \mathrm{~A})-\mathrm{Sn}(1 \mathrm{~A})-\mathrm{O}(3 \mathrm{~A}) 86.71(15)$ \\
\hline $\mathrm{Sn}(2 \mathrm{~A})-\mathrm{O}(2 \mathrm{~A}) 2.264(3)$ & $\mathrm{C}(5 \mathrm{~A})-\mathrm{Sn}(1 \mathrm{~A})-\mathrm{C}(1 \mathrm{~A}) 143.64(17)$ \\
\hline $\mathrm{Sn}(2 \mathrm{~A})-\mathrm{O}(5 \mathrm{~A}) 2.233(3)$ & $\mathrm{C}(1 \mathrm{~A})-\mathrm{Sn}(1 \mathrm{~A})-\mathrm{O}(1 \mathrm{~A})^{\# 1} 96.30(15)$ \\
\hline $\operatorname{Sn}(2 A)-C(28 A) 2.134(4)$ & $\mathrm{C}(1 \mathrm{~A})-\mathrm{Sn}(1 \mathrm{~A})-\mathrm{O}(3 \mathrm{~A}) 89.84(16)$ \\
\hline $\operatorname{Sn}(2 \mathrm{~A})-\mathrm{C}(32 \mathrm{~A}) 2.121(4)$ & $\mathrm{O}(1 \mathrm{~A})-\mathrm{Sn}(2 \mathrm{~A})-\mathrm{O}(4 \mathrm{~A}) 79.55(10)$ \\
\hline $\mathrm{P}(1 \mathrm{~A})-\mathrm{C}(49 \mathrm{~A}) 1.828(5)$ & $\mathrm{O}(1 \mathrm{~A})-\mathrm{Sn}(2 \mathrm{~A})-\mathrm{O}(2 \mathrm{~A}) 90.28(10)$ \\
\hline $\mathrm{P}(1 \mathrm{~A})-\mathrm{C}(43 \mathrm{~A}) 1.833(5)$ & $\mathrm{O}(1 \mathrm{~A})-\mathrm{Sn}(2 \mathrm{~A})-\mathrm{C}(28 \mathrm{~A}) 110.40(14)$ \\
\hline \multirow{7}{*}{$\mathrm{P}(1 \mathrm{~A})-\mathrm{C}(40 \mathrm{~A}) 1.833(4)$} & $\mathrm{O}(1 \mathrm{~A})-\mathrm{Sn}(2 \mathrm{~A})-\mathrm{C}(32 \mathrm{~A}) 107.88(15)$ \\
\hline & $\mathrm{O}(4 \mathrm{~A})-\mathrm{Sn}(2 \mathrm{~A})-\mathrm{O}(2 \mathrm{~A}) 169.36(10)$ \\
\hline & $\mathrm{C}(28 \mathrm{~A})-\mathrm{Sn}(2 \mathrm{~A})-\mathrm{O}(4 \mathrm{~A}) 97.01(14)$ \\
\hline & $\mathrm{C}(28 \mathrm{~A})-\mathrm{Sn}(2 \mathrm{~A})-\mathrm{O}(2 \mathrm{~A}) 83.53(14)$ \\
\hline & $\mathrm{C}(32 \mathrm{~A})-\mathrm{Sn}(2 \mathrm{~A})-\mathrm{O}(4 \mathrm{~A}) 94.83(14)$ \\
\hline & $\mathrm{C}(32 \mathrm{~A})-\mathrm{Sn}(2 \mathrm{~A})-\mathrm{O}(2 \mathrm{~A}) 91.24(14)$ \\
\hline & $\mathrm{C}(32 \mathrm{~A})-\mathrm{Sn}(2 \mathrm{~A})-\mathrm{C}(28 \mathrm{~A}) 141.35(18)$ \\
\hline
\end{tabular}

Symmetry transformations used to generate equivalent atoms: \#1 $-\mathrm{X}, 1-\mathrm{Y}, 1-\mathrm{Z}$.

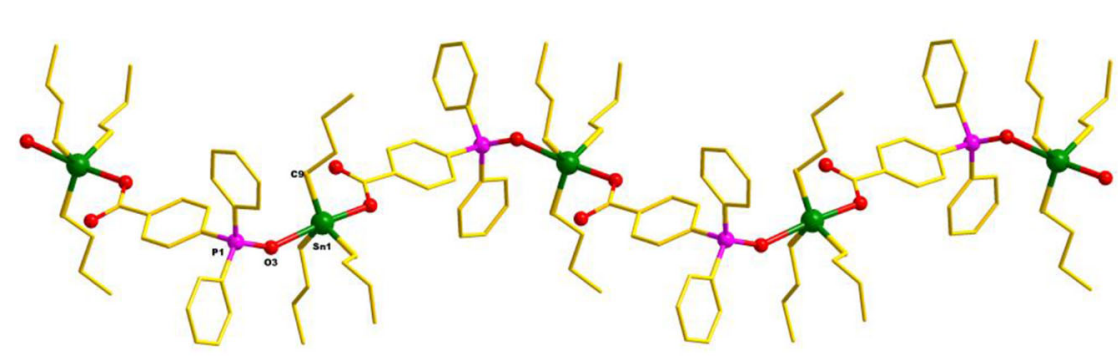

(a)

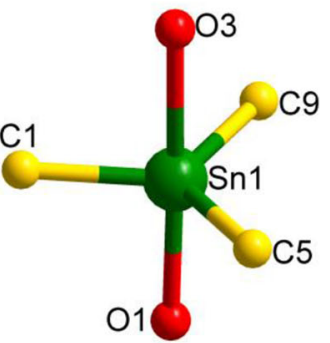

(b)

Figure 3. (a) Molecular structure of the organostannoxane 1-D coordination polymer 3. (b) Coordination environment around a tin atom (Sn1).

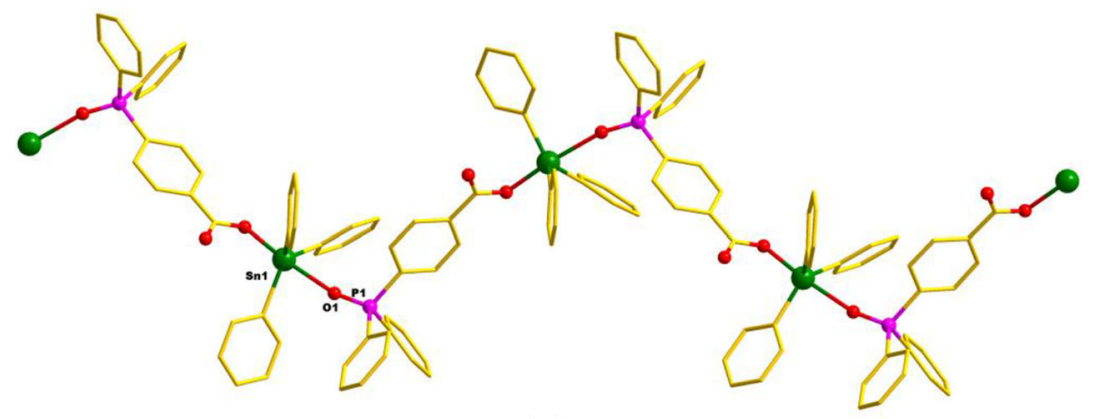

(a)

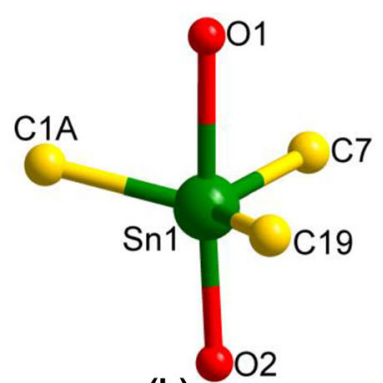

(b)

Figure 4. (a) Molecular structure of the organostannoxane 1-D coordination polymer 4. Hydrogen atoms and disordered part of the phenyl rings are omitted for clarity. (b) Coordination environment around a tin atom $(\mathrm{Sn} 1)$ in 4. 
Table 4. Selected bond parameters for compound 3.

\begin{tabular}{lc}
\hline Bond Lengths $(\AA)$ & Bond Angles $\left(^{\circ}\right)$ \\
\hline $\mathrm{Sn}(1)-\mathrm{O}(1) 2.1894(18)$ & $\mathrm{O}(1)-\mathrm{Sn}(1)-\mathrm{O}(3) 175.31(6)$ \\
$\mathrm{Sn}(1)-\mathrm{O}(3)$ 2.4295(18) & $\mathrm{C}(9)-\mathrm{Sn}(1)-\mathrm{O}(1) 98.60(9)$ \\
$\mathrm{Sn}(1)-\mathrm{C}(9) 2.138(3)$ & $\mathrm{C}(9)-\mathrm{Sn}(1)-\mathrm{O}(3) 86.00(8)$ \\
$\mathrm{Sn}(1)-\mathrm{C}(5) 2.141(3)$ & $\mathrm{C}(9)-\mathrm{Sn}(1)-\mathrm{C}(5) 117.44(11)$ \\
$\mathrm{Sn}(1)-\mathrm{C}(1) 2.136(3)$ & $\mathrm{C}(5)-\mathrm{Sn}(1)-\mathrm{O}(1) 87.91(9)$ \\
$\mathrm{P}(1)-\mathrm{O}(3) 1.4973(18)$ & $\mathrm{C}(5)-\mathrm{Sn}(1)-\mathrm{O}(3) 89.14(9)$ \\
$\mathrm{P}(1)-\mathrm{C}(20) 1.801(3)$ & $\mathrm{C}(1)-\mathrm{Sn}(1)-\mathrm{O}(1) 93.99(9)$ \\
$\mathrm{P}(1)-\mathrm{C}(26) 1.803(3)$ & $\mathrm{C}(1)-\mathrm{Sn}(1)-\mathrm{O}(3) 84.08(9)$ \\
$\mathrm{P}(1)-\mathrm{C}(13) 1.805(3)$ & $\mathrm{C}(1)-\mathrm{Sn}(1)-\mathrm{C}(9) 124.63(11)$ \\
& $\mathrm{C}(1)-\mathrm{Sn}(1)-\mathrm{C}(5) 116.71(11)$ \\
\hline
\end{tabular}

Table 5. Selected bond parameters for compound 4.

\begin{tabular}{lc}
\hline Bond Lengths $(\AA)$ & Bond Angles $\left(^{\circ}\right)$ \\
\hline Sn(1)-C(19) 2.1243(16) & $\mathrm{C}(19)-\mathrm{Sn}(1)-\mathrm{O}(2) 89.18(12)$ \\
$\mathrm{Sn}(1)-\mathrm{O}(2) 2.126(4)$ & $\mathrm{C}(19)-\mathrm{Sn}(1)-\mathrm{C}(7) 115.00(8)$ \\
$\mathrm{Sn}(1)-\mathrm{C}(7) 2.1302(17)$ & $\mathrm{O}(2)-\mathrm{Sn}(1)-\mathrm{C}(7) 99.35(13)$ \\
$\mathrm{Sn}(1)-\mathrm{C}(1 \mathrm{~A}) 2.2336(18)$ & $\mathrm{C}(19)-\mathrm{Sn}(1)-\mathrm{C}(1 \mathrm{~A}) 119.05(7)$ \\
$\mathrm{Sn}(1)-\mathrm{O}(1) 2.413(5)$ & $\mathrm{O}(2)-\mathrm{Sn}(1)-\mathrm{C}(1 \mathrm{~A}) 106.46(14)$ \\
$\mathrm{P}(1)-\mathrm{O}(1) 1.451(5)$ & $\mathrm{C}(7)-\mathrm{Sn}(1)-\mathrm{C}(1 \mathrm{~A}) 119.46(7)$ \\
$\mathrm{P}(1)-\mathrm{C}(21) 1.804(2)$ & $\mathrm{C}(19)-\mathrm{Sn}(1)-\mathrm{O}(1) 82.63(12)$ \\
$\mathrm{P}(1)-\mathrm{C}(33) 1.806(2)$ & $\mathrm{O}(2)-\mathrm{Sn}(1)-\mathrm{O}(1) 171.80(17)$ \\
$\mathrm{P}(1)-\mathrm{C}(27) 1.809(2)$ & $\mathrm{C}(7)-\mathrm{Sn}(1)-\mathrm{O}(1) 84.50(13)$ \\
& $\mathrm{C}(1 \mathrm{~A})-\mathrm{Sn}(1)-\mathrm{O}(1) 77.49(13)$ \\
\end{tabular}

The molecular structures of compounds $\mathbf{3}$ and $\mathbf{4}$ are shown in Figures 3 and 4, respectively. In these compounds the $\mathrm{R}_{3} \mathrm{Sn}[\mathrm{R}=n$ - $\mathrm{Bu}(3), \mathrm{Ph}(4)]$ unit is coordinated by the oxygen atoms arising from the carboxylate and the $\mathrm{P}=\mathrm{O}$ moiety in opposite directions resulting a 1-D coordination polymer. In these compounds the tin atoms are pentacoordinated $(3 \mathrm{C}, 2 \mathrm{O})$ in a trigonal bipyramidal geometry. In compound 3 , the $\mathrm{Sn}-$ O bonds of 2.189(4) $\AA$ and 2.429(5) $\AA$ are correspond to the $\mathrm{Sn}-\mathrm{O}-\mathrm{C}(=\mathrm{O})$ and $\mathrm{Sn}-\mathrm{O}=\mathrm{P}$ types respectively (Table 4). The average $\mathrm{Sn}-\mathrm{C}$ bond distance is 2.138(3) $\AA$. In compound 4, the Sn-O bonds of 2.126(4) $\AA$ and 2.413(5) $\AA$ belong to the $\mathrm{Sn}-\mathrm{O}-\mathrm{C}(=\mathrm{O})$ and $\mathrm{Sn}-\mathrm{O}=\mathrm{P}$ types respectively. The average $\mathrm{Sn}-\mathrm{C}$ bond distance is 2.162(5) A (Table 5).

\section{Conclusions}

We have utilized the organostannoxane synthesis approach to prepare functional compounds containing multi-site coordinating periphery. Thus, compounds containing six and four $-\mathrm{PPh}_{2}$ units have been readily prepared. In an effort to prepare analogous compounds containing triorgano groups, we observed an unexpected oxidation of the $\mathrm{PPh}_{2}$ groups to $\mathrm{P}(\mathrm{O}) \mathrm{Ph}_{2}$ groups.
The resulting coordination action of the phosphine oxide along with the carboxylate unit affords a onedimensional coordination polymer.

\section{Supplementary Information (SI)}

CCDC 1830820-1830824 containing crystal data of the compounds (1-4) can be obtained free of charge from The Cambridge Crystallographic Data Centre, 12 Union Road, Cambridge CB2 1 EZ, UK, (Fax: +44- (0)1223-336033 or Email: deposit@ccdc.cam.ac.uk); website: www.ccdc.cam. ac.uk/data_request/cif.

\section{Acknowledgements}

This work is supported by the Tata Institute of Fundamental Research Hyderabad, Hyderabad, Telangana, India. VC is thankful to the Department of Science and Technology for a J. C. Bose fellowship.

\section{References}

1. Amouri H, Desmarets C and Moussa J 2012 Confined Nanospaces in Metallocages: Guest Molecules, Weakly Encapsulated Anions, and Catalyst Sequestration Chem. Rev. 1122015

2. Roesky HW, Haiduc I and Hosmane NS 2003 Organometallic Oxides of Main Group and Transition Elements Downsizing Inorganic Solids to Small Molecular Fragments Chem. Rev. 1032579

3. Chandrasekhar V, Nagendran S and Baskar V 2002 Organotin assemblies containing Sn-O bonds Coord. Chem. Rev. 2351

4. García-Zarracino R and Höpfl H 2005 Self-Assembly of Diorganotin(IV) Oxides ( $\mathrm{R}=\mathrm{Me}, n \mathrm{Bu}, \mathrm{Ph})$ and 2,5Pyridinedicarboxylic Acid to Polymeric and Trinuclear Macrocyclic Hybrids with Porous Solid-State Structures: Influence of Substituents and Solvent on the Supramolecular Structure J. Am. Chem. Soc. 1273120

5. Beckmann J, Dakternieks D, Duthie A, Lewcenko N A and Mitchell C 2004 Carbon dioxide fixation by the cooperative effect of organotin and organotellurium oxides Angew. Chem. Int. Ed. $\mathbf{4 3} 6683$

6. Ma C and Sun J 2004 A novel self-assembling synthesis and crystal structure of 40-membered macrocyclic complex containing eight-tin Dalton Trans. 1785

7. Chandrasekhar V, Gopal K and Thilagar P 2007 Nanodimensional Organostannoxane Molecular Assemblies Acc. Chem. Res. 40420

8. Delavaux-Nicot, B, Kaeser A, Hahn U, Gegout A, Brandli PE, Duhayon C, Coppel Y, Saquet A and Nierengarten J-F 2008 Organotin chemistry for the preparation of fullerene-rich nanostructures J. Mater. Chem. 181547

9. Kundu S, Chakraborty A, Mondal K and Chandrasekhar V 2014 Multi-Ruthenocene Assemblies on an Organostannoxane Platform. Supramolecular Signatures and Conversion to (Ru-Sn)O ${ }_{2}$ Cryst. Growth Des. 14861

10. Kundu S, Metre R K, Yadav R, Sen P and Chandrasekhar V 2014 Multi-Pyrene Assemblies Supported on Stannoxane Frameworks: Synthesis, Structure and Photophysical Studies Chem. Asian J. 91403 
11. Chandrasekhar V, Thilagar P and Sasikumar P 2006 Multi-site coordination ligands assembled on organostannoxane supports J. Organomet. Chem. 6911681

12. Chandrasekhar V, Kundu S, Kumar J, Verma S, Gopal K, Chaturbedi A and Subramaniam K 2013 Supramolecular Signatures of Adenine-Containing Organostannoxane Assemblies Cryst. Growth Des. 131665

13. Chandrasekhar V, Narayanan R S and Thilagar P 2009 Organostannoxane-Supported Palladium Nanoparticles. Highly Efficient Catalysts for Suzuki-Coupling Reactions Organometallics $\mathbf{2 8} 5883$

14. Chandrasekhar V and Narayanan R S 2011 Organostannoxane-supported $\operatorname{Pd}(0)$ nanoparticles as efficient catalysts for Heck-coupling reactions Tetrahedron Lett. $\mathbf{5 2} 3527$

15. Chandrasekhar V and Narayanan R S 2013 Organostannoxane-supported $\operatorname{Pd}(0)$ nanoparticles as an efficient catalytic system for alkyne dimerization Ind. J. Chem. 52A 1066

16. International Tables for X-Ray Crystallography 1952 Vol. III. (Birmingham: Kynoch Press)
17. Sheldrick G M 1999 In $S A I N T+$, version 6.02 (Madison: Bruker AXS)

18. Sheldrick G M 1997 In SADABS, Empirical Absorption Correction Program (Germany: University of Göttingen)

19. CrysAlis PRO. 2014 (Yarnton, Oxfordshire: Agilent Technologies Ltd)

20. Sheldrick G M 2015 SHELXT - Integrated spacegroup and crystal-structure determination Acta Cryst. A71 3

21. Sheldrick G M 2015 Crystal structure refinement with SHELXL Acta Cryst. C71 3

22. Dolomanov O V, Bourhis L J, Gildea R J, Howard J A K and Puschmann H 2009 OLEX2: a complete structure solution, refinement and analysis program J. Appl. Crystallogr. 42339

23. Muller P 2006 In Crystal Structure Refinement: A Crystallographer's guide to SHELXL (New York: International Union of Crystallography and Oxford University Press) p.59.

24. Brandenburg K 2014 DIAMOND Version 3.2k, (Bonn: Crystal Impact GbR). 